This is a preprint that has not been peer-reviewed yet (2021-12-22).

Feedback related to the conducted study, non-cited literature, or suggestions for suitable research outlets, are very welcome.

\title{
Politically motivated aesthetic judgments
}

Arvid Erlandsson, Jennifer Rosander and Artur Nilsson

Linköping University, Sweden

Word count: 6394

Corresponding author arvid.erlandsson@liu.se

\begin{abstract}
Are people motivated to feel that clothes worn by members of their political ingroup (outgroup) are more (less) beautiful and valuable? Building on research on politically motivated judgments, affective polarization, and social distancing, this study investigated how aesthetic judgments about the design and color of clothes, and willingness to pay for identical clothes, changed among Swedes $(\mathrm{N}=638)$ after they learnt that the clothes were worn by politicians from their most- or least-liked party. The results supported both a negative outgroup effect (i.e., clothes associated with the least-liked party became less attractive) and a positive ingroup effect (i.e., clothes associated with the most-liked party became more attractive and valuable). Clothes worn by non-politicians were evaluated similarly after the identity of the person wearing them was revealed. Particularly the positive ingroup effect was stronger among rightists than leftists, consistent with theoretical accounts that posit ideological asymmetries in motivated reasoning and relational motivations.
\end{abstract}

Keywords: Political polarization; affective polarization; social distancing; party over policy effect; aesthetic judgments of clothes.

\section{Acknowledgments}

This research was financed by a generous grant from the Swedish Science Council (grant number: 2017-01827). The authors want to thank Amanda Lindkvist for support during data illustration.

The preregistration, stimuli material, supplementary material, raw data, variable key, and analysis code can be found on the project's OSF-page

https://osf.io/w2n5v/?view only=61feec7875d8440096f9456e1c9f3d00 
Politically motivated (or directional) thinking, which is underpinned by a desire to reach a politically desirable conclusion, has been studied extensively in psychological research. Studies have found, for instance, that people tend to evaluate information as more credible when it is framed as being consistent with their political position or partisanship (Ditto et al., 2019; Flynn et al., 2017). But do people also make politically motivated aesthetic judgments? Specifically, do they perceive a piece of clothing as more (or less) beautiful and valuable just because they see a politician from their favorite (or least favorite) party wearing it?

There are reasons to believe that people do make such politically motivated aesthetic judgments. Most generally, human beings are social creatures (Brown, 2000; Tajfel et al., 1979), and the human tendency to behave more favorably toward ingroup-members than toward outgroup-members, which can be driven both by ingroup love and outgroup hate (Brewer, 1999), is well-documented (Balliet et al., 2014). Although people can have several social identities at once (e.g., American, Hispanic, engineer), political ideology and partisan affiliation make up some of the strongest social identities in modern democratic societies (Iyengar et al., 2012), in which political choices have increasingly become more a matter of personal values, preferences, and identity than gender, ethnicity, and social class (Caprara \& Vecchione, 2017; Johnston et al., 2017).

Whether political opponents have moved further apart in terms of preferred policies or factual beliefs over time - that is, whether ideological polarization (Taber \& Lodge, 2006; Lewandowsky \& Oberauer, 2016) has occurred - is a matter controversy (Westfall et al., 2015). There is, however, a broader consensus on the notion that affective polarization, which happens when animosity between political in- and outgroups increases (Iyengar et al., 2019; Finkel et al., 2020), is on the rise in most countries, including Europe (Reiljan, 2019) and Sweden (Renström et al., 2019). For instance, longitudinal studies in the United States have suggested that people's negative feelings toward their political outgroups have grown more intense from 2010 to 2020 (Druckman et al., 2021; Finkel et al., 2020).

Affective polarization can be assessed in various ways, and recent research has suggested that there are at least two different kinds of operationalizations that tap into different forms of polarization (Druckman \& Levendusky, 2019). The first includes feeling thermometer measures, where affective polarization is measured in terms of the difference between attitudes of the political ingroup and the political outgroup (Lavrakas, 2008; Lelkes \& Westwood, 2017), and measures of trust toward ingroup (vs. outgroup) partisans or perceptions of traits that are representative of ingroups and outgroups (Garrett et al., 2014). The second, which is particularly relevant for the current research, includes preferred social distance measured in terms of questions about, for instance, how comfortable people would be to work with an outgroup-partisan (vs. ingroup-partisan) or to have their child marrying a person from the political outgroup (Levendusky \& Malhotra, 2016). 
Research has suggested that people avoid individuals from their political outgroups, for example, when deciding whose arguments to listen to (Frimer et al., 2017), whom to date (Mallinas et al., 2018), where to live (Motyl et al., 2014), whom to hire for a job (Gift \& Gift, 2015), and how much time to spend at a thanksgiving dinner (Chen \& Rohla, 2018). These behaviors exemplify social distancing that is direct in the sense that people avoid contact with individuals or groups, that are explicitly and obviously partisan.

Other studies have suggested that people tend to distance themselves from ambiguous policies or ideas that they perceive to be associated with their political outgroup. This "party over policy-effect" is usually tested by having participants read a policy suggestion while experimentally manipulating which political side suggested it, and people tend to be negative toward any policy that is proposed by their political outgroup and positive toward most policies suggested by the political ingroup (Cohen, 2003; Tannenbaum et al., 2017; van Boven et al., 2018; Verkuyten \& Maliepaard, 2013). This is a good example of partisan contact-phobia that is indirect in the sense that a potentially neutral policy can be "contaminated" simply by being suggested or endorsed by an individual's least-liked party.

Past studies have shown that perceived partisanship can influence economic behaviors and purchase intentions as well. For instance, one study found that US voters were more likely to purchase discounted gift cards when these had been used in the political campaign of their preferred party (vs. the campaign of the other party; McConnell et al., 2018), and another study found that people were less likely to pay visit to a restaurant that had sponsored their political outgroup and more likely to pay visit to a restaurant that had sponsored their political ingroup (Panagopoulos et al., 2020).

In the current research, we investigated whether people would also be more likely to make more positive (or more negative) aesthetic judgments and show higher (or lower) purchasing intentions toward a type of neutral product - specifically clothing - after it had become associated with their most- or least-liked political party. In other words, are people motivated to perceive clothes worn by members of their political ingroup as more beautiful and valuable and clothes worn by outgroup members as less beautiful and valuable?

\section{The Current Research}

A limitation of previous measures of politically motivated social distancing is that they are confounded by the political contents of the stimuli that participants evaluated. For instance, in studies of attitudes to policies, it is possible that people use outgroup and ingroup affiliation as informational cues about what they would think about the policy if they were fully informed. Likewise, in the aforementioned studies of purchasing intentions, it is likely that people thought that purchasing the products or services that were associated with political ingroups would financially reward these groups. These problems echo the more general methodological problem of separating motivated (directional) reasoning from other kinds of non-directional motives (Tappin et al., 2020). 
In the current research, we presented participants with pictures of non-political clothes and asked them to make aesthetic judgments about the design and color of these clothes and to report how much they were willing to pay for identical clothes. We used a novel repeated-measures design, in which the participants evaluated the same clothes both before and after they were shown a picture of a famous politician wearing them.

The main reason that we used clothes as the consumer product is that clothes are typically evaluated in terms of their visual attractiveness. Making aesthetic judgments about clothes is an inherently nonpolitical task that does not require any political knowledge that could confound the measure of distancing. Furthermore, the partisan association with the products was indirect and arbitrary in this study - the clothing-brands were not sponsoring any of the politicians who were shown in the pictures, and there was no political or personal gain or loss for the politician if people would change their aesthetic judgments. Therefore, effects documented in this paradigm would be clear evidence of politically motivated indirect social distancing in the aesthetic domain. Following the suggestion by van Boven \& Sherman (2021), to separate ingroup and outgroup influences on social norms, we hypothesized that two separate effects would occur:

A negative outgroup-effect: people find clothes less attractive and less valuable after learning about a random association between these clothes and their least-liked party.

A positive ingroup-effect: people find clothes more attractive after learning about a random association between these clothes and their most-liked party.

We tested both these effects on three dependent variables: perceived attractiveness of the design of the clothes, perceived attractiveness of the color of the clothes, and willingness to pay for identical clothes. To rule out mere exposure effects (i.e., that people find clothes more attractive the more they are exposed to them), we also asked the participants to rate clothes worn by non-politicians.

Moreover, we were interested in whether these effects are symmetrical (i.e., equally strong for leftist and rightist participants) or asymmetrical (i.e., more pronounced among leftists or rightists). Many studies have found that conservatives (vs. liberals) tend to exhibit greater ingroup centrism and relational motivation (Jost et al., 2018; McFarland et al., 2012; Waytz et al., 2019), and a greater proneness to cognitive biases and motivated thinking (Baron \& Jost, 2019; Jost, 2017). These findings suggest that we should see more ingroup and outgroup effects in aesthetic judgments among rightists than among leftists (cf., the rigidity-of-the-right hypothesis). On the other hand, some scholars have contended that the aforementioned tendencies are similar across partisan lines but stronger among ideological extremists and authoritarians in any political camp (Costello et al., 2021; Crawford \& Brandt, 2020, Ditto et al., 2019; Van Prooijen \& Krouwel, 2019). 
Another significant feature of the current research is that we collected data from a nationally representative sample of Swedes. Because the vast majority of studies in this area of research have been conducted in the United States, there is a need for research on representative samples from other countries (Gidron et al., 2019; Leeper \& Slothuus, 2014). It is particularly valuable to investigate whether the same kinds of affective polarization that occur between Democrats and Republicans in the context of the US biparty system occur also in European countries with multi-party systems and multifaceted ideological landscapes (Nilsson et al., 2020). As of 2021, there are no less than eight parties in Swedish parliament. The Left party (LP), Green party (GP), and Social-democratic party (S), which subscribe to socialist, environmentalist, and social-democratic ideologies respectively, make up the traditional left-wing parties. The Christian Democratic party (CD), Moderate party (M), and Sweden Democratic party (SD), which subscribe to social-conservative, liberal-conservative, and nationalist-conservative ideologies respectively, represent the right-wing parties. The Center $(\mathrm{C})$ and Liberal (L) parties, which are both based on social-liberal ideology, are traditionally center-right parties but have recently shifted alliances and are therefore difficult to categorize as clearly leftist or rightist.

\section{Method}

Participants were recruited through the independent data collection company PFM research. We requested 600 complete responses from a sample that was representative of the adult Swedish population in terms of gender, age, region, and political affiliation. The total sample size (after exclusions) ended up being 638 ( $51.3 \%$ female, $48.4 \%$ male: $M_{\text {age }}=49.31$ years, $\left.S D=16.26\right)$. The participants were told that the purpose of the study was to investigate how people perceive and evaluate clothes. ${ }^{1}$

The participants were first shown 17 pictures, each depicting a piece of clothing (e.g., a dress, jacket, blouse, or blazer), in a randomized order. The clothes were always worn by a person, but the pictures were cropped so that the face of the wearer was not visible. For each picture, the participants evaluated the "design and fit" and "the color" of the depicted clothes on visual analogue scales ranging from -50 ("Very ugly") to +50 ("Very beautiful"). In addition, they rated their willingness to purchase clothes for themselves or for someone they knew by choosing the highest price range that they would agree to pay for clothes identical to the depicted clothes. The suggested ranges were in 250SEK $(\approx \$ 30)$ increments so that a score of 1 represented 0-250 SEK and a score of 8 represented 1751-2000 SEK ( 9 $=2001 \mathrm{SEK}$ or more)

\footnotetext{
${ }^{1}$ The preregistration, stimuli material, supplementary material, raw data, variable key, and analysis code can be found on the project's OSF-page https://osf.io/w2n5v/?view_only=61feec7875d8440096f9456e1c9f3d00
} 
The participants thereafter reported their current age, their gender identity $(1=$ "Woman", 2 = "Man", $3=$ "Other/do not want to say"), their fashion interest ( 1 = "No interest", 7 = "Very interested"), their feelings toward each of the eight parties in the Swedish parliament (visual analogue scale: $-50=$ "Strongly dislike", $0=$ "Neither dislike nor like", $+50=$ "Strongly like"), the parties they liked the most and the least (forced-choice questions), and finally their left-right self-placement $(-50=$ "Strongly leftist", $+50=$ "Strongly rightist").

Participants then evaluated the same 17 clothes (in a randomized order) as in the first part of the study, as well as two additional pictures of clothes that were presented before the others. As before, they evaluated design, color, and how much they were willing to pay for identical clothes. The first additional picture was included to put the participants in a mindset that they would evaluate new clothes in this round. The second additional picture served as an attention check (the participants were asked to respond "501-750 SEK" to show that they were attentive).

The main difference from the first part of the study was that the pictures were no longer cropped, which means that the face of the wearer was visible. Three of the pictures were stock photos depicting unknown non-politicians (one man and two women), but the other 14 pictures showed well-known Swedish politicians. We included one male and one female politician from each of the three left-wing parties (LP, GP, and S) and from each of the three right-wing parties (CD, M and SD). Because $\mathrm{C}$ and $\mathrm{L}$ are not unequivocally left- or right-wing, these parties were represented by just one picture each showing their respective party leaders (both were women). We used existing photographs of politicians, but we matched pairs of pictures for the left- and right-wing parties so that the age, gender, pose, and type of clothing were as similar as possible. Name and party affiliation of the politician were written above the pictures to increase party salience. ${ }^{2}$

\section{Statistical Analyses}

As preregistered, participants who failed the attention check $(n=57)$ were screened out prior to the analyses. Participants who chose either LP, GP, or S as their most-liked party $(n=284)$ were classified as leftists whereas participants who chose either CD, M, or SD were classified as rightists $(n=267)$. Participants who chose $\mathrm{C}$ or $\mathrm{L}$ as their most-liked party $(n=87)$ were excluded from analyses that compared leftist and rightist participants. As a robustness check, we repeated the analyses with political placement based on least-liked parties and on political left-right self-placement; results of these tests are reported in the supplementary material posted on OSF, and summarized in the general discussion. Statistical analyses were done in SPSS version 28.0.0.0 unless stated otherwise. All manipulations, measures, and exclusions are reported.

\footnotetext{
${ }^{2}$ Finally, participants again reported their feelings toward each of the eight parties represented in the Swedish parliament using the same response scale as before (feelings toward parties are not reported in this manuscript, but all variables are included in the data file).
} 
To test the hypotheses, we first conducted a 3 (Partisan association of clothes: Most-liked party/Leastliked party/Non-political) * 2 (Time: 1 [without political cues]/2[with political cues]) repeated measures ANOVA for each dependent variable. A significant interaction effect would indicate that people's evaluations of clothes are influenced by the induced partisan association. We followed up significant interactions with paired $t$-tests (comparing change from Time 1 to Time 2) for each dependent variable (design, color, and willingness to pay) to test the negative outgroup and positive ingroup effects separately and to test if evaluations of clothes worn by non-politicians changed between Time 1 and Time 2 .

To investigate the presence of ideological asymmetries in the magnitude of the effects, we conducted mixed 2 (Participant: leftist/rightist) * 2 (Time: 1[without political cues] /2[with political cues]) ANOVAs with evaluations of color, design, and willingness to pay for clothes associated with the participant's most-liked party (the ingroup effect) and the least-liked party (the outgroup effect) as the dependent variables (i.e., six mixed ANOVAs in total). A significant interaction effect on evaluations of clothes associated with the most liked party would indicate that the ingroup effect is moderated by participants political orientation (and vice versa for the outgroup effect). We subsequently added changes in corresponding evaluations (design, color, or willingness to pay) for non-political clothes as a covariate in a first step and fashion interest as a covariate in a second step to gauge the robustness of the effects. We did not to add gender or age as covariates because they both correlated with having a rightist most-liked party (male gender: $r=.16, p<.001$; age: $r=.11, p=.009$ ), which means that including them as covariates would entail a risk of corrupting the interaction we were interested in (Miller \& Chapman, 2001).

Because standard null-hypothesis testing cannot provide support for the null hypothesis (a nonsignificant result can always be due to limited statistical power), we used equivalence testing to test for the absence of a meaningful difference (Lakens, 2017; Lakens et al., 2018). We did this by comparing leftist and rightist participants (classified based on their most-liked party) in terms of their change scores (i.e., evaluations at Time 1 subtracted from evaluations at Time 2). A significant nullhypothesis test for the interaction terms together with a non-significant equivalence test for the change scores would indicate that the compared means differ in a meaningful way. The smallest effect size of interest (SESOI) was set to $d_{z}=0.25$ for the paired $t$-tests and $d=0.25$ for the independent $t$-tests. The rationale for this was that effect sizes smaller than this should have very limited practical significance. The power for detecting these effect sizes with the sample size in this study was over $99 \%$ for the mixed ANOVAs and 90\% for the independent $t$-tests (Faul et al., 2007).

We followed our preregistration with respect to sample size, handling of outliers, and hypotheses. We did, however, deviate mildly from the preregistered plan for the analyses. The initial plan was that the main analyses would aggregate evaluations of clothes worn by leftist politicians and clothes worn by 
rightist politicians and compare leftist and rightist participants' change in evaluations toward all leftist and rightist clothes in a 2(Time 1/Time 2) *2(Leftist/Rightist clothes) $* 2$ (Leftist/Rightist participant) ANOVA. The rationale for this aggregation was that it would increase the reliability of the estimates. The analyses of changes in evaluations of clothes worn by politicians form the participant's most-liked and least-liked parties were described as secondary analyses in the pre-registration. Nevertheless, we ultimately decided to report results from the analyses based on least- and most-liked party in the main text, because this classification more directly maps onto ingroup- and outgroup affiliations, and there was substantial variability in the participants' feelings toward different left- and right-wing parties. Results based on the left vs. right classification of the clothes are reported in the supplementary material on OSF.

We added non-preregistered Holm-Bonferroni corrections of the alpha thresholds for the six statistical hypotheses we tested (three for the ingroup effect and three for the outgroup effect) to prevent inflation of Type 1 error rates. All effects that were originally significant $(p<.05)$ remained significant (with alpha thresholds ranging from .008 to .017).

\section{Results}

The mean evaluations for the 17 clothes before (Time 1) and after (Time 2) a partisan association between clothes and politician was introduced are reported in Table 1. Changes in evaluations of mostliked, least-liked and non-political clothes are reported in Table 2 and illustrated in Figure 1.

\section{Test of Ingroup and Outgroup Effects}

Consistent with the hypotheses, there were significant Partisan association*Time interaction effects on ratings of the design of the clothes, $F(2,636)=40.62, \eta_{p}{ }^{2}=.11$, the color of the clothes, $F(2,636)=$ $24.56, \eta_{p}{ }^{2}=.07$, and how much the participants were willing to pay for them, $F(2,636)=15.61, \eta_{p}{ }^{2}$ $=.05$ (all $p<.001)$. See supplementary material on OSF for information about the main effects.

Follow-up $t$-tests indicated that there was no significant change between Time 1 and Time 2 in ratings of the design $\left(M_{\text {change }}=+.62 ; d_{z}=.07\right.$ [CI95 of $\left.\left.d_{z}:-.01, .14\right]\right)$ and color $\left(M_{\text {change }}=+.52 ; d_{z}=.06\right.$ $[-.02, .13])$ of clothes worn by unknown non-politicians. Willingness to pay for clothes worn by nonpoliticians was slightly higher at Time 2 , but equivalence tests showed that this change was smaller than our SESOI $\left(M_{\text {change }}=+.10 ; d_{z}=.16[.08, .24]\right.$; see Table 2$)$. Taken together, the results suggest that evaluations of clothes worn by non-politicians did not change in any meaningful way when the identity of the wearer was revealed, consistent with our expectations.

For clothes worn by a politician from the participant's least-liked party, ratings of the design ( $M_{\text {change }}=$ $\left.-3.70, d_{z}=-.26[-.33,-.18]\right)$ and color $\left(M_{\text {change }}=-3.70 d_{z}=-.26[-.33,-.18]\right)$ decreased significantly but 
the willingness to pay did not $\left(M_{\text {change }}=-.06 d_{z}=-.07[-.15, .01]\right)$. For clothes worn by a politician from the participant's most-liked party, ratings of the design $\left(\mathrm{M}_{\text {change }}=+2.74 ; d_{z}=.21[.13, .29]\right)$ and willingness to pay ( $\left.M_{\text {change }}=+.20 ; d_{z}=.23[.15, .30]\right)$ increased but ratings of the color did not change much $\left(M_{\text {change }}=+.41 ; d_{z}=.03[-.04, .11]\right.$; see Table 2$)$.

These results provide evidence of negative outgroup effects in aesthetic judgments of the design and color of clothes (but not the amount of money the participants were willing to pay). Further, they provide evidence of positive ingroup effects on judgments concerning the design (but not the color) and the amount of money the participants were willing to pay for the clothes. 
Table 1

Means and standard deviations for design, color, and willingness to pay for all clothes and numbers of participants who chose each party as their most-liked and least-liked.

\begin{tabular}{|c|c|c|c|c|c|c|c|c|}
\hline \multirow[t]{2}{*}{$\begin{array}{l}\text { Identity of } \\
\text { wearer }\end{array}$} & \multicolumn{2}{|c|}{ Design } & \multicolumn{2}{|c|}{ Color } & \multicolumn{2}{|c|}{$\begin{array}{c}\text { Willingness to } \\
\text { pay }\end{array}$} & \multirow{3}{*}{$\begin{array}{c}\text { Most- liked } \\
\text { party }(n) \\
\\
167\end{array}$} & \multirow{3}{*}{$\begin{array}{c}\begin{array}{c}\text { Least- liked } \\
\text { party }(n)\end{array} \\
40\end{array}$} \\
\hline & Time 1 & Time 2 & Time 1 & Time 2 & Time 1 & Time 2 & & \\
\hline $\begin{array}{l}\text { Social } \\
\text { Democratic }\end{array}$ & & & & & & & & \\
\hline Löfven (S) & $\begin{array}{l}17.13 \\
(20.42)\end{array}$ & $\begin{array}{l}14.13 \\
(21.92)\end{array}$ & $\begin{array}{l}21.17 \\
(20.14)\end{array}$ & $\begin{array}{l}17.93 \\
(20.92)\end{array}$ & $\begin{array}{c}4.02 \\
(2.02)\end{array}$ & $\begin{array}{c}3.95 \\
(2.07)\end{array}$ & & \\
\hline Andersson (S) & $\begin{array}{c}7.52 \\
(21.59)\end{array}$ & $\begin{array}{c}7.54 \\
(22.27)\end{array}$ & $\begin{array}{c}9.19 \\
(22.83)\end{array}$ & $\begin{array}{c}7.15 \\
(23.72)\end{array}$ & $\begin{array}{c}2.61 \\
(1.54)\end{array}$ & $\begin{array}{c}2.76 \\
(1.61)\end{array}$ & & \\
\hline Left & & & & & & & 74 & 69 \\
\hline Sjöstedt (LP) & $\begin{array}{c}8.92 \\
(21.18)\end{array}$ & $\begin{array}{c}5.79 \\
(21.18)\end{array}$ & $\begin{array}{c}8.09 \\
(23.19)\end{array}$ & $\begin{array}{c}5.87 \\
(22.69)\end{array}$ & $\begin{array}{c}3.48 \\
(1.97)\end{array}$ & $\begin{array}{c}3.37 \\
(1.86)\end{array}$ & & \\
\hline Dadgostar (LP) & $\begin{array}{c}-5.58 \\
(23.64)\end{array}$ & $\begin{array}{l}-5.50 \\
(24.01)\end{array}$ & $\begin{array}{c}9.25 \\
(22.11)\end{array}$ & $\begin{array}{c}5.47 \\
(23.22)\end{array}$ & $\begin{array}{l}1.73 \\
(1.02)\end{array}$ & $\begin{array}{c}1.88 \\
(1.14)\end{array}$ & & \\
\hline Green & & & & & & & 43 & 149 \\
\hline Lövin (GP) & $\begin{array}{l}10.66 \\
(20.97)\end{array}$ & $\begin{array}{c}7.54 \\
(21.56)\end{array}$ & $\begin{array}{c}5.76 \\
(22.93)\end{array}$ & $\begin{array}{c}1.99 \\
(23.15)\end{array}$ & $\begin{array}{c}2.80 \\
(1.60)\end{array}$ & $\begin{array}{c}2.77 \\
(1.56)\end{array}$ & & \\
\hline Fridolin (GP) & $\begin{array}{c}11.64 \\
(20.37)\end{array}$ & $\begin{array}{c}10.01 \\
(20.36) \\
\end{array}$ & $\begin{array}{c}16.05 \\
(19.39) \\
\end{array}$ & $\begin{array}{c}13.39 \\
(19.56) \\
\end{array}$ & $\begin{array}{c}3.44 \\
(1.82) \\
\end{array}$ & $\begin{array}{c}3.45 \\
(1.75) \\
\end{array}$ & & \\
\hline $\begin{array}{l}\text { Christian } \\
\text { Democrat }\end{array}$ & & & & & & & 35 & 22 \\
\hline Hägglund (CD) & $\begin{array}{l}12.59 \\
(21.05)\end{array}$ & $\begin{array}{l}10.86 \\
(20.66)\end{array}$ & $\begin{array}{c}13.57 \\
(22.68)\end{array}$ & $\begin{array}{l}11.80 \\
(21.47)\end{array}$ & $\begin{array}{c}3.65 \\
(1.94)\end{array}$ & $\begin{array}{c}3.63 \\
(1.98)\end{array}$ & & \\
\hline Busch (CD) & $\begin{array}{c}3.53 \\
(22.81)\end{array}$ & $\begin{array}{c}4.51 \\
(23.92)\end{array}$ & $\begin{array}{c}7.13 \\
(23.79)\end{array}$ & $\begin{array}{c}7.62 \\
(24.89)\end{array}$ & $\begin{array}{l}1.89 \\
(1.16)\end{array}$ & $\begin{array}{c}2.19 \\
(1.38)\end{array}$ & & \\
\hline Moderate & & & & & & & 139 & 11 \\
\hline Kristersson (M) & $\begin{array}{l}-11.77 \\
(23.39)\end{array}$ & $\begin{array}{c}-4.78 \\
(22.60)\end{array}$ & $\begin{array}{c}0.78 \\
(24.06)\end{array}$ & $\begin{array}{c}3.30 \\
(23.53)\end{array}$ & $\begin{array}{c}2.63 \\
(1.77)\end{array}$ & $\begin{array}{c}3.11 \\
(1.98)\end{array}$ & & \\
\hline Kinberg Batra (M) & $\begin{array}{l}15.21 \\
(21.13)\end{array}$ & $\begin{array}{l}12.16 \\
(21.85)\end{array}$ & $\begin{array}{c}8.48 \\
(23.79)\end{array}$ & $\begin{array}{c}7.15 \\
(24.35)\end{array}$ & $\begin{array}{c}2.88 \\
(1.73)\end{array}$ & $\begin{array}{c}2.95 \\
(1.70)\end{array}$ & & \\
\hline $\begin{array}{l}\text { Sweden } \\
\text { Democrat }\end{array}$ & & & & & & & 93 & 315 \\
\hline Åkesson (SD) & $\begin{array}{l}13.70 \\
(21.39)\end{array}$ & $\begin{array}{c}6.89 \\
(24.77)\end{array}$ & $\begin{array}{c}6.75 \\
(25.99)\end{array}$ & $\begin{array}{c}3.45 \\
(27.42)\end{array}$ & $\begin{array}{c}2.88 \\
(1.73)\end{array}$ & $\begin{array}{c}3.09 \\
(1.85)\end{array}$ & & \\
\hline Stegrud (SD) & $\begin{array}{l}-9.24 \\
(22.17)\end{array}$ & $\begin{array}{c}-4.20 \\
(21.91)\end{array}$ & $\begin{array}{c}7.39 \\
(21.99)\end{array}$ & $\begin{array}{c}8.08 \\
(22.51)\end{array}$ & $\begin{array}{c}2.11 \\
(1.30)\end{array}$ & $\begin{array}{c}2.37 \\
(1.44)\end{array}$ & & \\
\hline $\begin{array}{l}\text { Uncategorized } \\
\text { parties }\end{array}$ & & & & & & & & \\
\hline Lööf (Center) & $\begin{array}{c}10.47 \\
(19.68)\end{array}$ & $\begin{array}{c}6.82 \\
(22.00)\end{array}$ & $\begin{array}{c}3.97 \\
(24.37)\end{array}$ & $\begin{array}{c}.55 \\
(25.22)\end{array}$ & $\begin{array}{c}2.73 \\
(1.66)\end{array}$ & $\begin{array}{c}2.72 \\
(1.66)\end{array}$ & 60 & 16 \\
\hline Sabuni (Liberal) & $\begin{array}{c}13.77 \\
(24.64)\end{array}$ & $\begin{array}{c}12.44 \\
(25.43)\end{array}$ & $\begin{array}{c}15.37 \\
(23.94)\end{array}$ & $\begin{array}{c}13.45 \\
(24.64)\end{array}$ & $\begin{array}{c}3.21 \\
(1.89)\end{array}$ & $\begin{array}{c}3.17 \\
(1.82)\end{array}$ & 27 & 16 \\
\hline Controls & & & & & & & & \\
\hline Olsson & $\begin{array}{c}13.67 \\
(21.37)\end{array}$ & $\begin{array}{c}14.66 \\
(21.44)\end{array}$ & $\begin{array}{c}13.10 \\
(23.07)\end{array}$ & $\begin{array}{c}14.53 \\
(22.79)\end{array}$ & $\begin{array}{c}3.00 \\
(1.65)\end{array}$ & $\begin{array}{c}3.08 \\
(1.68)\end{array}$ & & \\
\hline Karlsson & $\begin{array}{c}-3.61 \\
(23.07)\end{array}$ & $\begin{array}{c}-2.13 \\
(22.92)\end{array}$ & $\begin{array}{c}-7.49 \\
(25.82)\end{array}$ & $\begin{array}{c}-5.72 \\
(24.70)\end{array}$ & $\begin{array}{c}2.25 \\
(1.49)\end{array}$ & $\begin{array}{c}2.35 \\
(1.50)\end{array}$ & & \\
\hline Nilsson & $\begin{array}{c}8.85 \\
(22.42)\end{array}$ & $\begin{array}{c}8.24 \\
(22.83)\end{array}$ & $\begin{array}{c}13.58 \\
(21.94)\end{array}$ & $\begin{array}{c}11.95 \\
(21.73)\end{array}$ & $\begin{array}{c}2.34 \\
(1.31)\end{array}$ & $\begin{array}{c}2.45 \\
(1.37)\end{array}$ & & \\
\hline
\end{tabular}


Table 2

Mean evaluations at Time 1 (before identity of wearer is known) and Time 2 (when identity is known) for clothes worn by non-political people and by politicians from each participant's least-liked and most-liked party, and the correlation between Time 1 and 2 evaluations.

\begin{tabular}{|c|c|c|c|c|c|c|}
\hline & $\begin{array}{l}\text { Time } 1 \\
\text { Mean } \\
{[95 \mathrm{CI}]}\end{array}$ & $\begin{array}{l}\text { Time } 2 \text { Mean } \\
{[95 \mathrm{CI}]}\end{array}$ & $r$ & $\begin{array}{l}\text { Null- } \\
\text { hypothesis test }\end{array}$ & $\begin{array}{l}\text { Equivalence } \\
\text { test }\end{array}$ & Interpretation \\
\hline \multicolumn{7}{|l|}{ Non-political } \\
\hline Design & $\begin{array}{l}6.31 \\
{[5.05,7.56]}\end{array}$ & $\begin{array}{l}6.92 \\
{[5.64-8.20]}\end{array}$ & .84 & $\begin{array}{l}t(637)=1.71 \\
p=.088\end{array}$ & $p<.001$ & No change \\
\hline Color & $\begin{array}{l}6.40 \\
{[5.10,7.69]}\end{array}$ & $\begin{array}{l}6.92 \\
{[5.64-8.20]}\end{array}$ & .84 & $\begin{array}{l}t(637)=1.42 \\
p=.157\end{array}$ & $p<.001$ & No change \\
\hline $\begin{array}{l}\text { Willingness } \\
\text { to pay }\end{array}$ & $\begin{array}{l}2.53 \\
{[2.43,2.62]}\end{array}$ & $\begin{array}{l}2.63 \\
{[2.53-2.73]}\end{array}$ & .88 & $\begin{array}{l}t(637)=4.07, \\
p<.001\end{array}$ & $p=.013$ & $\begin{array}{l}\text { Change too } \\
\text { small to be of } \\
\text { interest }\end{array}$ \\
\hline \multicolumn{7}{|l|}{$\begin{array}{l}\text { Least-liked } \\
\text { party }\end{array}$} \\
\hline Design & $\begin{array}{l}5.86 \\
{[4.45,7.28]}\end{array}$ & $\begin{array}{l}2.16 \\
{[0.63-3.69]}\end{array}$ & .71 & $\begin{array}{l}t(637)=-6.46 \\
p<.001\end{array}$ & $p=.564$ & $\begin{array}{l}\text { Negative } \\
\text { outgroup- } \\
\text { effect }\end{array}$ \\
\hline Color & $\begin{array}{l}9.18 \\
{[7.77,10.59]}\end{array}$ & $\begin{array}{l}5.47 \\
{[3.92-7.03]}\end{array}$ & .72 & $\begin{array}{l}t(637)=-6.44 \\
p<.001\end{array}$ & $p=.578$ & $\begin{array}{l}\text { Negative } \\
\text { outgroup- } \\
\text { effect }\end{array}$ \\
\hline $\begin{array}{l}\text { Willingness } \\
\text { to pay }\end{array}$ & $\begin{array}{l}2.83 \\
{[2.71,2.94]}\end{array}$ & $\begin{array}{l}2.76 \\
{[2.64-2.88]}\end{array}$ & .79 & $\begin{array}{l}t(637)=-1.71 \\
p=.089\end{array}$ & $p<.001$ & No change \\
\hline \multicolumn{7}{|l|}{$\begin{array}{l}\text { Most-liked } \\
\text { party }\end{array}$} \\
\hline Design & $\begin{array}{l}6.67 \\
{[5.21,8.13]}\end{array}$ & $\begin{array}{l}9.41 \\
{[7.94-10.89]}\end{array}$ & .77 & $\begin{array}{l}t(637)=5.38 \\
p<.001\end{array}$ & $p=.189$ & $\begin{array}{l}\text { Positive } \\
\text { ingroup- } \\
\text { effect }\end{array}$ \\
\hline Color & $\begin{array}{l}8.76 \\
{[7.25,10.28]}\end{array}$ & $\begin{array}{l}9.17 \\
{[7.67-10.68]}\end{array}$ & .80 & $\begin{array}{l}t(637)=.84 \\
p=.403\end{array}$ & $p<.001$ & No change \\
\hline $\begin{array}{l}\text { Willingness } \\
\text { to pay }\end{array}$ & $\begin{array}{l}2.92 \\
{[2.80,3.04]}\end{array}$ & $\begin{array}{l}3.13 \\
{[3.00-3.25]}\end{array}$ & .84 & $\begin{array}{l}t(637)=5.68 \\
p<.001\end{array}$ & $p=.322$ & $\begin{array}{l}\text { Positive } \\
\text { ingroup- } \\
\text { effect }\end{array}$ \\
\hline
\end{tabular}

Note: A significant null-hypothesis test together with a non-significant equivalence test indicates that evaluations changed in a meaningful way. Smallest effect size of interest (SESOI) was set at $d_{z}=0.25$. 


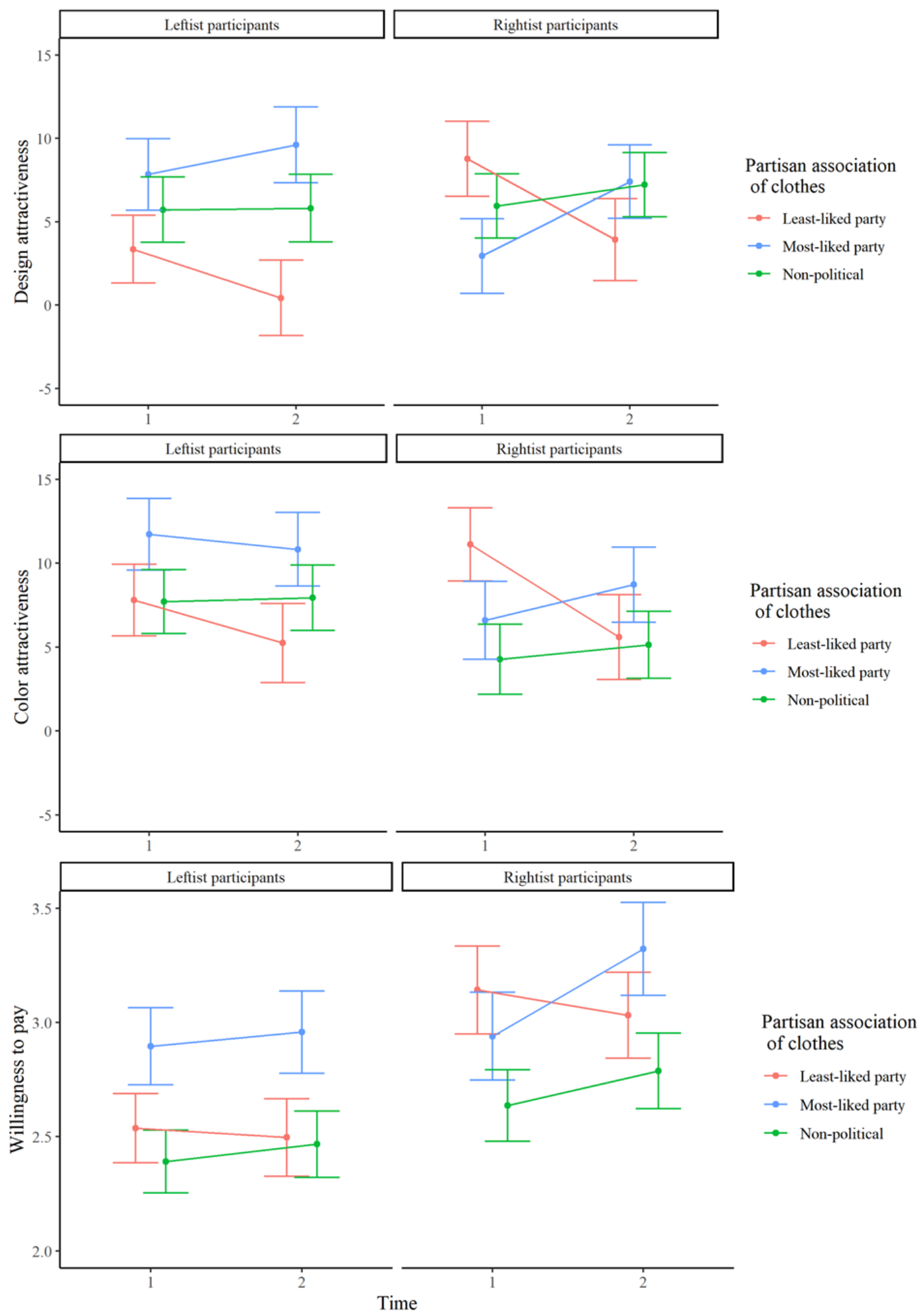

Figure 1. Change in evaluations from Time 1 to Time 2 for perceived design attractiveness (top panel) color attractiveness (middle panel) and willingness to pay (bottom panel), when the clothes were worn by people from the participant's most-liked party (blue line) and least-liked party (red line) and by non-politicians (green line). Downward red slopes indicate negative outgroup-effects. Upward blue slopes indicate positive ingroup-effects. Error bars indicate 95\% confidence intervals. 


\section{Tests of Ideological Symmetries and Asymmetries}

A series of mixed ANOVAs revealed that the positive ingroup effect was consistently stronger among rightist participants. There were significant interaction effects of Most-liked party * Time on evaluations of the design of the clothes, $F(1,549)=6.20, p=.013, \eta_{p}{ }^{2}=.011$, the color of the clothes, $F(1,549)=8.21, p=.004, \eta_{p}{ }^{2}=.015$, and how much the participants were willing to pay for identical clothes, $F(1,549)=17.70, p<.001, \eta_{p}{ }^{2}=.031$. All these interaction effects remained significant when we entered changes in evaluations for non-political clothes (design, color, or willingness to pay respectively) from Time 1 to Time 2 and fashion interest as covariates: design, $F(1,547)=4.69, p$ $=.031, \eta_{p}{ }^{2}=.009$; color, $F(1,547)=7.89, p=.005, \eta_{p}{ }^{2}=.014$; and willingness to pay, $F(1,547)=$ $15.34, p<.001, \eta_{p}^{2}=.027$.

Results concerning the negative outgroup effect were all in the direction of stronger effects among rightist participants as well, but there was a significant difference between leftist and rightist participants only for the evaluations of the color of the clothes: $F(1,549)=5.50, p=.019, \eta_{p}{ }^{2}=.010$ (with both covariates: $F[1,547]=6.40, p=.012, \eta_{p}{ }^{2}=.012$. There were no significant differences in the evaluation of the design of the clothes, $F(1,549)=2.38, p=.123, \eta_{p}{ }^{2}=.004$ (with both covariates: $\left.F[1,547]=2.96, p=.086, \eta_{p}{ }^{2}=.005\right)$, or the willingness to pay for the clothes, $F(1,549)=.73, p$ $=.392, \eta_{p}{ }^{2}=.001$ (with both covariates: $F[1,547]=1.31, p=.253, \eta_{p}{ }^{2}=.002$ ).

With respect to the covariates, changes in non-political evaluations of the clothes consistently moderated the ingroup effect ( $\left.p \leq .008, \eta_{p}{ }^{2} \geq .009\right)$ and the outgroup effect $\left(p \leq .001, \eta_{p}{ }^{2} \geq .020\right)$, but fashion interest had no significant effects on the ingroup effect $\left(p \geq .18, \eta_{p}{ }^{2} \leq .003\right)$ or the outgroup effect $\left(p \geq .24, \eta_{p}^{2} \leq .002\right)$.

To perform equivalence tests, we computed changes scores. These are shown in Table 3, along with results from the equivalence tests and from independent t-tests comparing the change scores of leftists and rightist participants. Equivalence was obtained only for willingness to pay for clothes worn by politicians from the least-liked party and for evaluations of the color of clothes worn by nonpoliticians. In other words, we can conclude that the differences between leftists and rightists were beneath the stipulated threshold for a meaningful effect only for these two dependent variables (out of nine in total).

Taken together, these results suggest that there are ideological asymmetries in politically motivated aesthetic judgments such that rightists exhibit a stronger positive ingroup effect, but the results are less conclusive with regards to the negative outgroup effect. 
Table 3

Mean change scores (and standard deviations) for leftist participants (those indicating the social democratic, left or green party as their most-liked party) and rightist participants (those indicating the Christian democratic, Moderate or Sweden democratic party as their most-liked) for each of the three dependent variables.

\begin{tabular}{|c|c|c|c|c|c|c|}
\hline & \multicolumn{2}{|c|}{ Change score } & \multirow[b]{2}{*}{$\begin{array}{l}\text { Cohen's } d \\
\text { [CI95] }\end{array}$} & \multirow[b]{2}{*}{$\begin{array}{l}\text { Null- } \\
\text { hypothe } \\
\text { sis test }\end{array}$} & \multirow[b]{2}{*}{ Equivalence test } & \multirow[b]{2}{*}{ Interpretation } \\
\hline & $\begin{array}{l}\text { Leftists } \\
(n=284)\end{array}$ & $\begin{array}{l}\text { Rightists } \\
(n=267)\end{array}$ & & & & \\
\hline \multicolumn{7}{|l|}{ Non-political } \\
\hline Design & $\begin{array}{l}+.09 \\
(9.56)\end{array}$ & $\begin{array}{l}+1.27 \\
(9.29)\end{array}$ & $\begin{array}{l}.13 \\
{[-.04, .29]}\end{array}$ & $p=.144$ & $p=.072$ & Undetermined \\
\hline Color & $\begin{array}{l}+.23 \\
(9.77)\end{array}$ & $+.86(8.82)$ & $\begin{array}{l}.07 \\
{[-.10, .23]}\end{array}$ & $p=.431$ & $p=.016$ & No difference \\
\hline $\begin{array}{l}\text { Willingness } \\
\text { to pay }\end{array}$ & $+.07(.60)$ & $+.15(.66)$ & $\begin{array}{l}.12 \\
{[-.05, .29]}\end{array}$ & $p=.167$ & $p=.075$ & Undetermined \\
\hline \multicolumn{7}{|c|}{ Least-liked party } \\
\hline Design & $\begin{array}{l}-2.92 \\
(13.78)\end{array}$ & $\begin{array}{l}-4.85 \\
(15.53)\end{array}$ & $\begin{array}{l}-.13 \\
{[-.30, .04]}\end{array}$ & $p=.125$ & $p=.083$ & Undetermined \\
\hline Color & $\begin{array}{l}-2.56 \\
(15.07)\end{array}$ & $\begin{array}{l}-5.52 \\
(14.48)\end{array}$ & $\begin{array}{l}-.20 \\
{[-.37,-.03]}\end{array}$ & $p=.019$ & $p=.280$ & $\begin{array}{l}\text { Rightists show } \\
\text { a stronger } \\
\text { outgroup effect }\end{array}$ \\
\hline $\begin{array}{l}\text { Willingness } \\
\text { to pay }\end{array}$ & $-.04(.95)$ & $-.11(.97)$ & $\begin{array}{l}-.07 \\
{[-.24, .09]}\end{array}$ & $p=.392$ & $p=.019$ & No difference \\
\hline \multicolumn{7}{|c|}{ Most-liked party } \\
\hline Design & $\begin{array}{l}+1.77 \\
(11.21)\end{array}$ & $\begin{array}{l}+4.47 \\
(13.74)\end{array}$ & $\begin{array}{l}.21 \\
{[.05, .38]}\end{array}$ & $p=.014$ & $p=.345$ & $\begin{array}{l}\text { Rightists show } \\
\text { a stronger } \\
\text { ingroup effect }\end{array}$ \\
\hline Color & $\begin{array}{l}-.90 \\
(11.50)\end{array}$ & $\begin{array}{l}+2.12 \\
(13.22)\end{array}$ & $\begin{array}{l}.24 \\
{[.08, .41]}\end{array}$ & $p=.005$ & $p=.471$ & $\begin{array}{l}\text { Rightists show } \\
\text { a stronger } \\
\text { ingroup effect }\end{array}$ \\
\hline $\begin{array}{l}\text { Willingness } \\
\text { to pay }\end{array}$ & $+.06(.74)$ & $+.38(1.04)$ & $\begin{array}{l}.36 \\
{[.19, .53]}\end{array}$ & $p<.001$ & $p=.889$ & $\begin{array}{l}\text { Rightists show } \\
\text { a stronger } \\
\text { ingroup effect }\end{array}$ \\
\hline
\end{tabular}

Note: A positive [negative] change score indicates that revealing the identity of the wearer made evaluations more positive [negative]. A significant null-hypothesis test together with a non-significant equivalence test indicates that leftists and rightists change scores differ in a meaningful way. Smallest effect size of interest (SESOI) was set at $d_{z}=0.25$. 


\section{Discussion}

This research is the first to demonstrate politically motivated aesthetic judgments. The results provided evidence for both ingroup and outgroup effects (for two out of three dependent variables each) on how attractive and valuable people find a piece of clothing after it has become arbitrarily associated with their most- or least-liked political party. Specifically, the participants found clothes both more attractive in terms of their design and worth a higher price after they had seen picture of a politician from their most-liked party wearing them, and they found clothes less attractive in terms of both design and color after they had seen a picture of a politician from their least-liked party wearing them. These results advance the growing bodies of research on motivated judgments (Ditto et al., 2019; Flynn et al., 2017) and affective polarization (Iyengar et al., 2019; Finkel et al., 2020) in general, and on politically motivated social distancing (Motyl et al., 2014; Gift \& Gift, 2015) and the "party over policy"-paradigm (van Boven et al., 2018; Verkuyten \& Maliepaard, 2013) in particular. They provide clear evidence of indirect politically motivated social distancing in the aesthetic domain.

The results of this study also provide some evidence of ideological asymmetries in politically motivated aesthetic judgments. Rightists (vs. leftists) consistently exhibited a stronger ingroup effect, with greater increases in attractiveness ratings and in how much they were willing to pay for the clothes after these had become associated with their preferred party. Although rightists decreased color evaluations of least-liked party clothes slightly more than leftists, the outgroup effect was more symmetric across partisan lines. ${ }^{3}$ These results are consistent with accounts positing ideological asymmetries in relational motivations and cognitive biases (e.g., Jost, 2017; Waytz et al., 2019), and suggest that differences between rightists and leftists pertain more to conformity with the ingroup than to animosity toward the outgroup.

There are several notable strengths of the current research. First, while most previous research has used convenience samples from the US, we recruited a representative sample from Sweden, which has multi-party system with a more ideologically heterogeneous political landscape (Gidron et al., 2019; Knudsen, 2021; Nilsson et al., 2020). Second, the paradigm we introduced permits stronger conclusions about motivated judgments than do many other common paradigms: aesthetic judgments of clothes that are arbitrarily associated with a political party are unlikely to be confounded by political beliefs or intentions to reward or punish a particular group, and the repeated measures design we used allowed us to isolate the effect of the arbitrary partisan association. Third, in contrast to studies that, for instance, contrast people's reactions to their most-liked party against reactions to all other parties on average (Renström et al., 2020), we disentangled effects of affiliation with the ingroup

\footnotetext{
${ }^{3}$ The results were similar but not identical when classifying participants based on their least-liked party or based on their political self-placement. No matter type of classification, rightist participants demonstrated a stronger ingroup effect than leftists for all outcome variables. Nevertheless, we found no evidence of asymmetries for the outgroup effect with the least-liked or self-placement classifications. See supplementary material on OSF.
} 
and distancing toward the outgroup, because studies have suggested that outgroup aversion is a stronger identity cue than ingroup affection nowadays (e.g. Finkel et al., 2020). Fourth, because there are multiple legitimate ways to classify participants in terms of party preference within a multiparty system, we repeated the analyses based on different classifications as a robustness test (see supplementary material on OSF). Fifth, we empirically tested not just the presence of ideological asymmetries but also the presence of symmetries, which cannot be validly inferred from the lack of significant differences (Lakens, 2017).

Limitations of the current research include that we only used clothes as the non-political product that was to be associated (or "contaminated") by partisanship. Clothes play a central role in defining and communicating social identities (Feinberg et al., 1992). The results can therefore not tell us whether politically motivated aesthetic judgments occur more broadly also for consumer products such as chocolate bars or toothpastes that are less outwardly visible and less important for social identity. Furthermore, this study did not investigate underlying causal mechanisms. It cannot tell us, for instance, whether effects were driven by a need to affiliate and identify with ingroup members, an internalized fear of social sanctions for liking an outfit worn by an outgroup politician, a false perception that the evaluations of the clothes reward an ingroup or an outgroup, or emotional reactions of disgust or admiration evoked by the politicians that were shown in the pictures.

Another limitation is that we only used members of the political elite (i.e., Swedish party leaders) as the source of the partisan associations with the non-political product. The results can therefore not tell us whether introducing an association between a non-political product and a non-elite partisan would produce similar effects. Theories of cultural evolution propose that people use dominance and prestige as cues to success and therefore tend to imitate people who possess these qualities (Henrich, 2015), which suggests that the origins of the partisan association may play a critical role. Future research could therefore investigate how evaluations and purchase intentions of non-political products change when the origin of the association is, for instance, an unknown identified individual who votes for the participant's most- or least-liked party, a famous person who is not a politician, or a norm or general tendency to like a particular product within a political in- or outgroup. 


\section{References}

Balliet, D., Wu, J., \& De Dreu, C. K. (2014). Ingroup favoritism in cooperation: a meta-analysis. Psychological Bulletin, 140(6), 1556.

Baron, J., \& Jost, J. T. (2019). False equivalence: Are liberals and conservatives in the United States equally biased? Perspectives on Psychological science, 14(2), 292-303.

van Boven, L., Ehret, P. J., \& Sherman, D. K. (2018). Psychological barriers to bipartisan public support for climate policy. Perspectives on Psychological science, 13(4), 492-507.

van Boven, L., \& Sherman, D. K. (2021). Elite influence on public attitudes about climate policy. Current Opinion in Behavioral Sciences, 42, 83-88.

Brewer, M. B. (1999). The psychology of prejudice: Ingroup love and outgroup hate? Journal of social issues, 55(3), 429-444. doi:10.1111/0022-4537.00126

Brown, R. (2000). Social identity theory: Past achievements, current problems and future challenges. European Journal of Social Psychology, 30(6), 745-778.

Caprara, G. V., \& Vecchione, M. (2017). Personalizing politics and realizing democracy: Oxford University Press.

Chen, M. K., \& Rohla, R. (2018). The effect of partisanship and political advertising on close family ties. Science, 360(6392), 1020-1024.

Cohen, G. L. (2003). Party over policy: The dominating impact of group influence on political beliefs. Journal of Personality and Social Psychology, 85(5), 808.

Costello, T. H., Bowes, S. M., Stevens, S. T., Waldman, I. D., Tasimi, A., \& Lilienfeld, S. O. (2021). Clarifying the structure and nature of left-wing authoritarianism. Journal of Personality and Social Psychology.

Crawford, J. T., \& Brandt, M. J. (2020). Ideological (a) symmetries in prejudice and intergroup bias. Current Opinion in Behavioral Sciences, 34, 40-45.

Ditto, P. H., Liu, B. S., Clark, C. J., Wojcik, S. P., Chen, E. E., Grady, R. H., . . Zinger, J. F. (2019). At least bias is bipartisan: A meta-analytic comparison of partisan bias in liberals and conservatives. Perspectives on psychological science, 14(2), 273-291.

Druckman, J. N., Klar, S., Krupnikov, Y., Levendusky, M., \& Ryan, J. B. (2021). Affective polarization, local contexts and public opinion in America. Nature Human Behaviour, 5(1), 28-38.

Druckman, J. N., \& Levendusky, M. S. (2019). What do we measure when we measure affective polarization? Public opinion quarterly, 83(1), 114-122.

Faul, F., Erdfelder, E., Lang, A.-G., \& Buchner, A. (2007). G*Power 3: A flexible statistical power analysis program for the social, behavioral, and biomedical sciences. Behavior research methods, 39(2), 175-191. doi:10.3758/bf03193146

Feinberg, R. A., Mataro, L., \& Burroughs, W. J. (1992). Clothing and social identity. Clothing and Textiles Research Journal, 11(1), 18-23.

Finkel, E. J., Bail, C. A., Cikara, M., Ditto, P. H., Iyengar, S., Klar, S., . . Rand, D. G. (2020). Political sectarianism in America. Science, 370(6516), 533-536.

Flynn, D., Nyhan, B., \& Reifler, J. (2017). The nature and origins of misperceptions: Understanding false and unsupported beliefs about politics. Political psychology, 38, 127-150.

Frimer, J. A., Skitka, L. J., \& Motyl, M. (2017). Liberals and conservatives are similarly motivated to avoid exposure to one another's opinions. Journal of Experimental Social Psychology, 72, 112.

Garrett, R. K., Gvirsman, S. D., Johnson, B. K., Tsfati, Y., Neo, R., \& Dal, A. (2014). Implications of pro-and counterattitudinal information exposure for affective polarization. Human Communication Research, 40(3), 309-332.

Gidron, N., Adams, J., \& Horne, W. (2019). Toward a comparative research agenda on affective polarization in mass publics. APSA Comparative Politics Newsletter, 29, 30-36.

Gift, K., \& Gift, T. (2015). Does politics influence hiring? Evidence from a randomized experiment. Political Behavior, 37(3), 653-675.

Henrich, J. (2015). Culture and social behavior. Current Opinion in Behavioral Sciences, 3, 84-89. 
Iyengar, S., Lelkes, Y., Levendusky, M., Malhotra, N., \& Westwood, S. J. (2019). The origins and consequences of affective polarization in the United States. Annual Review of Political Science, 22, 129-146.

Iyengar, S., Sood, G., \& Lelkes, Y. (2012). Affect, not ideology: A social identity perspective on polarization. Public opinion quarterly, 76(3), 405-431.

Johnston, C. D., Lavine, H. G., \& Federico, C. M. (2017). Open versus closed: Personality, identity, and the politics of redistribution: Cambridge University Press.

Jost, J. T. (2017). Ideological asymmetries and the essence of political psychology. Political psychology, 38(2), 167-208.

Jost, J. T., van der Linden, S., Panagopoulos, C., \& Hardin, C. D. (2018). Ideological asymmetries in conformity, desire for shared reality, and the spread of misinformation. Current Opinion in Psychology, 23, 77-83.

Knudsen, E. (2021). Affective Polarization in Multiparty Systems? Comparing Affective Polarization Towards Voters and Parties in Norway and the United States. Scandinavian Political Studies, 44(1), 34-44.

Lakens, D. (2017). Equivalence tests: A practical primer for $\mathrm{t}$ tests, correlations, and meta-analyses. Social Psychological and Personality Science, 8(4), 355-362.

Lakens, D., Scheel, A. M., \& Isager, P. M. (2018). Equivalence testing for psychological research: A tutorial. Advances in Methods and Practices in Psychological Science, 1(2), 259-269.

Lavrakas, P. J. (2008). Encyclopedia of survey research methods: Sage publications.

Leeper, T. J., \& Slothuus, R. (2014). Political parties, motivated reasoning, and public opinion formation. Political psychology, 35, 129-156.

Lelkes, Y., \& Westwood, S. J. (2017). The limits of partisan prejudice. The Journal of Politics, 79(2), 485-501.

Levendusky, M., \& Malhotra, N. (2016). Does media coverage of partisan polarization affect political attitudes? Political Communication, 33(2), 283-301.

Lewandowsky, S., \& Oberauer, K. (2016). Motivated rejection of science. Current Directions in Psychological Science, 25(4), 217-222.

Mallinas, S. R., Crawford, J. T., \& Cole, S. (2018). Political opposites do not attract: The effects of ideological dissimilarity on impression formation. Journal of Social and Political Psychology, 6(1), 49-75.

McConnell, C., Margalit, Y., Malhotra, N., \& Levendusky, M. (2018). The economic consequences of partisanship in a polarized era. American Journal of Political Science, 62(1), 5-18.

McFarland, S., Webb, M., \& Brown, D. (2012). All humanity is my ingroup: A measure and studies of identification with all humanity. Journal of Personality and Social Psychology, 103(5), 830853. doi:10.1037/a0028724

Miller, G. A., \& Chapman, J. P. (2001). Misunderstanding analysis of covariance. Journal of abnormal psychology, 110(1), 40.

Motyl, M., Iyer, R., Oishi, S., Trawalter, S., \& Nosek, B. A. (2014). How ideological migration geographically segregates groups. Journal of Experimental Social Psychology, 51, 1-14.

Nilsson, A., Montgomery, H., Dimdins, G., Sandgren, M., Erlandsson, A., \& Taleny, A. (2020). Beyond 'Liberals' and 'Conservatives': Complexity in Ideology, Moral Intuitions, and Worldview Among Swedish Voters. European Journal of Personality, 34(3), 448-469. doi:10.1002/per.2249

Panagopoulos, C., Green, D. P., Krasno, J., Schwam-Baird, M., \& Endres, K. (2020). Partisan Consumerism: Experimental Tests of Consumer Reactions to Corporate Political Activity. The Journal of Politics, 82(3), 000-000.

van Prooijen, J.-W., \& Krouwel, A. P. (2019). Psychological features of extreme political ideologies. Current Directions in Psychological Science, 28(2), 159-163.

Reiljan, A. (2020). 'Fear and loathing across party lines'(also) in Europe: Affective polarisation in European party systems. European journal of political research, 59(2), 376-396.

Renström, E. A., Bäck, H., \& Schmeisser, Y. (2019). Vi gillar olika: Om affektiv polarisering bland svenska väljare. In U. Andersson, A. Carlander, \& P. Öhberg (Eds.), Regntunga skyar. Göteborgs Universitet. 
Taber, C. S., \& Lodge, M. (2006). Motivated skepticism in the evaluation of political beliefs. American Journal of Political Science, 50(3), 755-769.

Tajfel, H., Turner, J. C., Austin, W. G., \& Worchel, S. (1979). An integrative theory of intergroup conflict. Organizational identity: A reader, 56(65), 9780203505984-9780203505916.

Tannenbaum, D., Fox, C. R., \& Rogers, T. (2017). On the misplaced politics of behavioural policy interventions. Nature Human Behaviour, 1(7), 1-7.

Tappin, B. M., Pennycook, G., \& Rand, D. G. (2020). Thinking clearly about causal inferences of politically motivated reasoning: Why paradigmatic study designs often undermine causal inference. Current Opinion in Behavioral Sciences, 34, 81-87.

Verkuyten, M., \& Maliepaard, M. (2013). A further test of the "party over policy" effect: Political leadership and ethnic minority policies. Basic and Applied Social Psychology, 35(3), 241-248.

Waytz, A., Iyer, R., Young, L., Haidt, J., \& Graham, J. (2019). Ideological differences in the expanse of the moral circle. Nature Communications, 10(1), 1-12.

Westfall, J., Van Boven, L., Chambers, J. R., \& Judd, C. M. (2015). Perceiving political polarization in the United States: Party identity strength and attitude extremity exacerbate the perceived partisan divide. Perspectives on psychological science, 10(2), 145-158. 